

\section{DISCLAIMER}

This report was prepared as an account of work sponsored by an agency of the United States Government. Neither the United States Government nor any agency Thereof, nor any of their employees, makes any warranty, express or implied, or assumes any legal liability or responsibility for the accuracy, completeness, or usefulness of any information, apparatus, product, or process disclosed, or represents that its use would not infringe privately owned rights. Reference herein to any specific commercial product, process, or service by trade name, trademark, manufacturer, or otherwise does not necessarily constitute or imply its endorsement, recommendation, or favoring by the United States Government or any agency thereof. The views and opinions of authors expressed herein do not necessarily state or reflect those of the United States Government or any agency thereof. 


\section{DISCLAIMER}

Portions of this document may be illegible in electronic image products. Images are produced from the best available original document. 


\section{NOTICE}

This report was prepared as an account of work sponsored by the United States Fovernment Neither the United States nor the United States Energy Research and Development Administration, nor any of their employees, nor any of their contractors, subcontractors, or their employees, makes any warranty, express or implied, or assumes any legal liability or responsibility for the accuracy, completeness or usefulness of any information, apparatus, product or process disclosed, or represents that its use would not infringe privately owned rights.

This report has been reproduced directly from the best available copy.

Available from the National Technical Information Service, U. S. Department of Commerce, Springfield, Virginia 22161

Price: Paper Copy $\$ 3.50$ (domestic)

$\$ 6.00$ (foreign)

Microfiche $\$ 2.25$ (domestic)

$\$ 3.75$ (foreign) 


\title{
DEVELOPMENT OF METHODS AND PROCEDURES FOR HIGH RATE LOW ENERGY EXPENDITURE FABRICATION OF SOLAR CELLS
}

\author{
QUARTERLY PROGRESS REPORT NO. 2
}

APRIL 1976

\section{A. R. KIRKPATRICK}

\section{J. A. MINNUCCI}

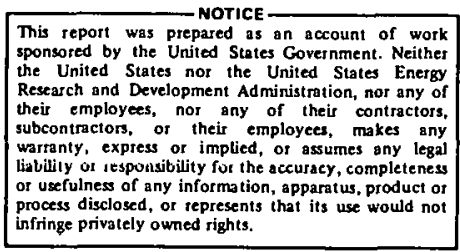

PERIOD COVERED 1 JAN. - 31 MARCH 1976

JPL CONTRACT NO. 954289

THIS WORK WAS PERFORMED FOR THE JET PROPULSION LABORATORY. CALIFORNIA INSTITUTE OF TECHNOLOGY SPONSORED BY THE NATIONAL AERONAUTICS AND SPACE ADMINISTRATION UNDER CONTRACT NAS7 - 100.

\section{SIMULATION PHYSICS}


THIS PAGE

\section{WAS INTENTIONALLY LEFT BLANK}




\section{ABSTRACT}

This program involves ion implantation and processing by pulsed electron beams to fabricate silicon solar cells in vacuum at high speed without the use of high temperature operations. Individual elements of the method are being successfully developed and program objectives are being approached.

This report contains information prepared by Simulation Physics, Inc. under JPL subcontract. Its content is not necessarily endorsed by the Jet Propulsion Laboratory, California Institute of Technology, or by the National Aeronautics and Space Administration. 
TABLE OF CONTENTS

SECTION

PAGE

1 INTRODUCTION

1

2 TECHNICAL DISCUSSION 3

2.1 Ion Implantation 3

2.2 Contacts 6

2.3 Wafer Sizing . . . 9

2.4 Pulsed Electron Beam Development 12

2.5 Processing Sequence 13

3 CONCLUSIONS AND RECOMMENDATIONS 15

4 APPENDICES 17

4.1 New Technology 17

4.2 Program Plan 17

4.3 Man Hours and Costs 17 


\subsection{INTRODUCTION}

Simulation Physics is developing an approach to fabri-. cation of silicon solar cells which promises to be fast, inexpensive and efficient in its utilization of materials and energy. The development is based upon the use of ion implantation in conjunction with pulsed energy methods replacing conventional thermal operations to allow fabrication of cells entirely under vacuum with the cell, wafer maintained at room temperature throughout processing. The program objective is to accomplish fabrication of approximately $11 \%$ efficient (AMO)

$2 \times 2 \mathrm{~cm}$ cells with actual process duration less than 120 seconds and cell surface energy deposition less than 5 calories/ $\mathrm{cm}^{2}$.

Status of the program as of January 1976 was given in Quarterly Report No. 1. At that time ion implanted solar cells had been demonstrated using only vacuum operations performed at room temperature. Best cell performance achieved was approximately $9 \%$ AMO with cell currents and curve factors equivalent to those observed with conventionally processed ion implanted cells but with open circuit voltages slightly lower.

During the past three months effort has involved development of individual procedures which are to be combined for achievement of program objectives. Implantation conditions for phosphorus and boron to produce an $\mathrm{N}^{+} / \mathrm{PP}^{+}$structure are being 
investigated. Cell metallization development has emphasized aluminum in order to minimize cost and process complexity. Pulsed electron beam capability has been extended to allow processing of larger areas. Cell fabrication sequences have been shortened such that total process time objectives are now being approached. 
2.0 TECHNICAL DISCUSSION

2.1 Ion Implantation

Equipment used for ion implantation is inherently expensive and complex. It is probable that in a full scale solar cell production facility based upon the processing concepts being developed under this program, the implanters used for introduction of the junction and back contact underlayers will determine throughput limitations.

The ion implanter at Simulation Physics delivers scanned beams of $200 \mu \mathrm{A}$ of phosphorus or $50 \mu \mathrm{A}$ of boron at energies between 25 and $200 \mathrm{keV}$. Lower beam currents are produced at energies down to $5 \mathrm{keV}$. High current machines are available which deliver up to $3 \mathrm{~mA}$ of phosphorus and $1 \mathrm{~mA}$ of boron. Next generation machines of up to $100 \mathrm{~mA}$ are now under conceptual design.

Experimental work on junction introduction has involved examination of implant energies from 5 through $200 \mathrm{keV}$ and fluences from $5 \times 10^{13}$ to $10^{16}$ ions $/ \mathrm{cm}^{2}$. Best cell performance characteristics are achieved at lowest energy and modest fluence. However such cells are for several reasons not compatible with the processing constraints of this particular program. Phosphorus implant parameters expected to be utilized for process demon-strations of this program remain as $1 \times 10^{15}$ ions $/ \mathrm{cm}^{2}$ at $25 \mathrm{keV}$. In $10 \mathrm{ohm}-\mathrm{cm}$ material resulting junction depth and sheet 


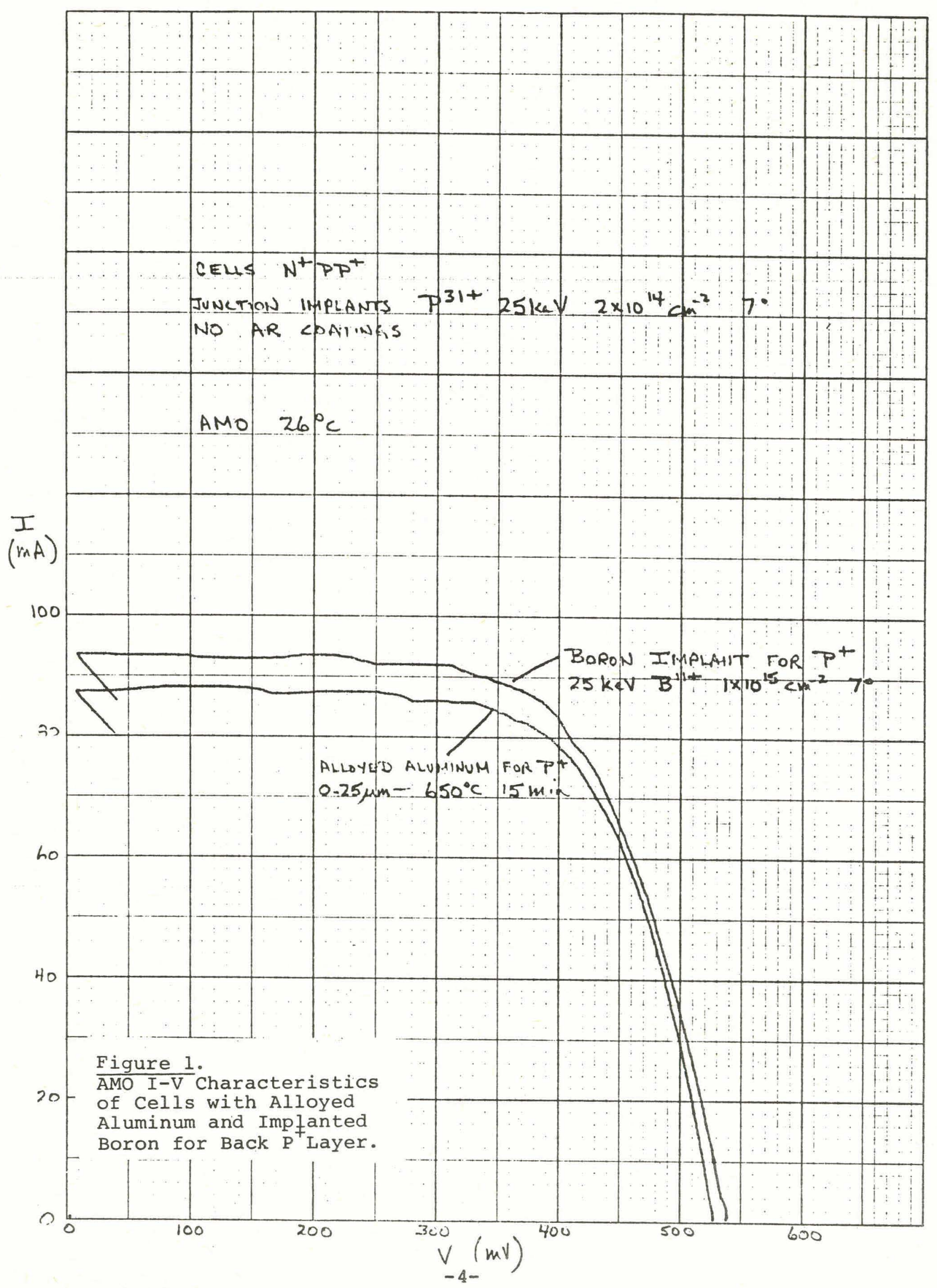


resistance are approximately $0.3 \mu \mathrm{m}$ and $100 \mathrm{ohms} / 0$ respectively. Cell area throughput capabilities of $200 \mu \mathrm{A}, 3 \mathrm{~mA}$ and $100 \mathrm{~mA}$ implanters under $10^{15}$ ions $/ \mathrm{cm}^{2}$ fluence requirements are 1.2 , 18 and $600 \mathrm{~cm}^{2}$ per second respectively.

The all vacuum processing being developed assumes a clean, properly surfaced silicon wafer to start but does not provide for cleaning, etching or other alteration of the wafer surfaces during fabrication. Application of an adequate ohmic back contact to the lightly doped cell base region is difficult in these circumstances and it is expected that it will be necessary to utilize a $\mathrm{P}^{+}$underlayer at the interface. Usually alloyed aluminum is excellent for this purpose but in the present case, in order to minimize processing time, the necessary heavy surface doping will be produced by boron ion implantation. Investigation is in progress to identify minimum conditions for satisfactory $\mathrm{P}^{+}$layers by boron implant. Figure 1 compares AMO I-V characteristics of otherwise identically processed cells with $\mathrm{P}^{+}$layers introduced by alloying an evaporated aluminum layer at $650^{\circ} \mathrm{C}$ for 15 minutes and by implanting $10^{15}$ boron ions per $\mathrm{cm}^{2}$ at $25 \mathrm{keV}$. In the experiment implants were furnace annealed at $750^{\circ} \mathrm{C}$ for one hour and titanium silver contents were sintered at $605^{\circ} \mathrm{C}$ for 5 minutes. Although they show somewhat low curve factors due to low fluence junction implants, both cells of Figure 1 exhibit satisfactory back contact behavior. 
It is planned that front and back contacts of cells to be fabricated will be of aluminum deposited by vacuum evaporation then pulse sintered. In conjunction with the back surface $\mathrm{P}^{+}$underlayer investigation, a test was conducted to determine the electrical quality of contacts deposited directly onto a polished surface of a lightly doped silicon wafer. Aluminum was alloyed into the back surface of a number of $10 \Omega$-cm $\mathrm{P}$-type silicon wafers without junctions. The back surfaces were then metallized to produce low resistance ohmic contacts. Onto the polished front surfaces of these wafers were evaporated arrays of $0.3 \mathrm{~cm}$ square metallization patches. For purposes of comparison, both titanium-silver and aluminum were used with depositions performed onto substrates at room temperature and at $250^{\circ} \mathrm{C}$. Dark current-voltage characteristics were then measured between front and back metallization on each sample type as deposited and after furnace sintering or pulsed sintering in an electron beam.

Two types of behavior of the contacts to the polished silicon were observed and are illustrated in the examples of Figures 2 and 3. Aluminum contacts, except those deposited at room temperature and not subsequently sintered, were ohmic at approximately $3 \mathrm{ohms}$ corresponding to the silicon wafer resistance in the configuration used. As in the example of Figure 3 , 


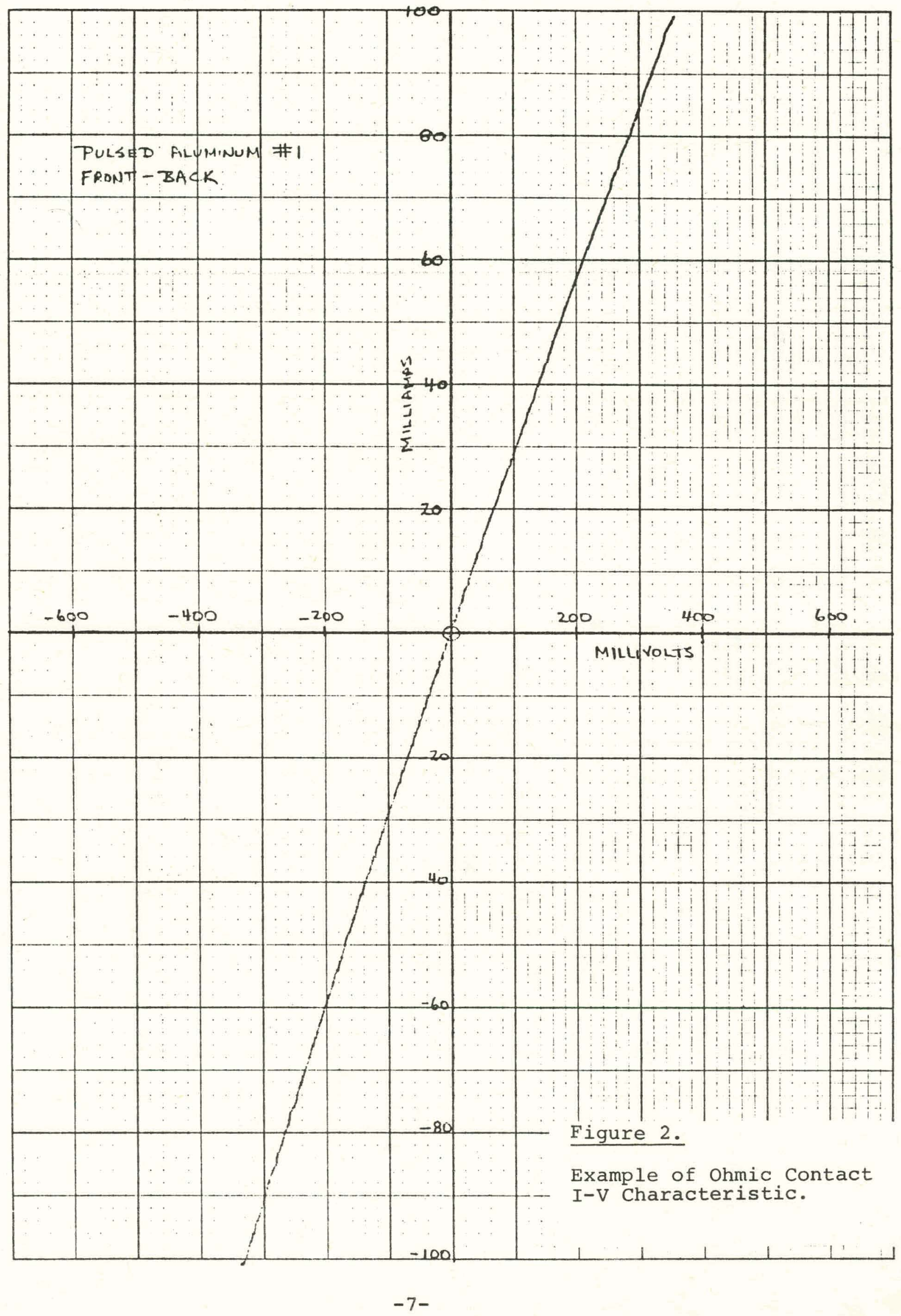




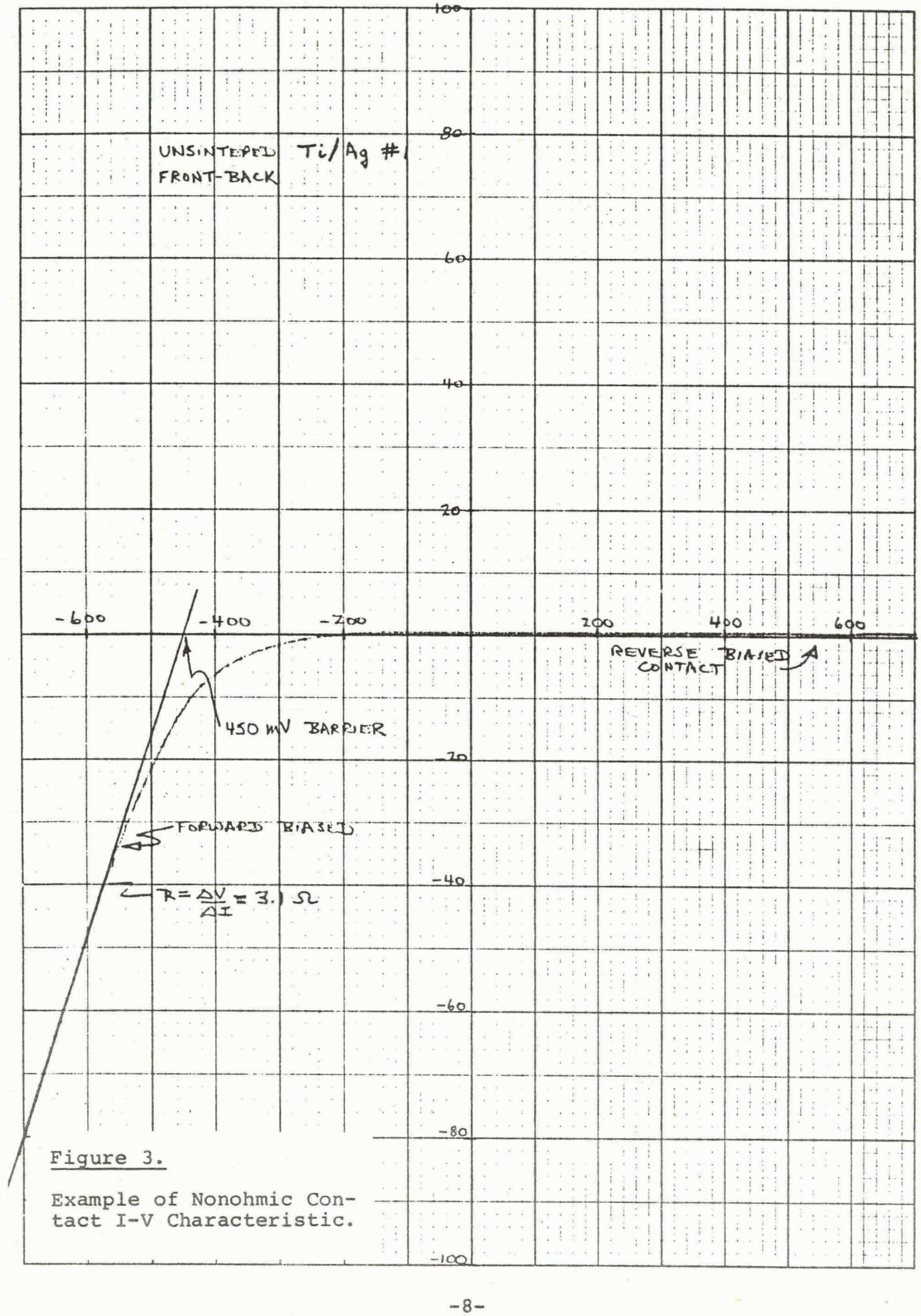


the room temperature unsintered aluminum contacts and all of the titanium-silver samples showed blocking behavior in one direction and a forward pattern characterized by an approximately 3 ohm resistance after reaching a turn-on or barrier voltage. Results are summarized in Table 1.

The aluminum contacts, either furnace or pulse sintered, exhibited good performance even in the absence of a $\mathrm{P}^{+}$underlayer. The results suggest that for aluminum contacts, the boron implant on the cell back surface may not be essential. The titaniumsilver contacts showed definite need for the $\mathrm{P}^{+}$interface and also showed that the particular pulse sintering conditions employed were in this case not sufficient.

\subsection{Wafer Sizing}

The solar cell junction must not extend down the wafer edge to form a connecting path from front to back contact. In the case of the ion implanted cell this requires that the wafer edge be masked during implant or that the finished cell be cut from an oversized wafer. An almost trivial possibility associated with pulse processing which might be of use in a completely automated cell fabrication and array encapsulation facility involves sizing the cell to a scribed pattern by the transient stress wave generated from the implant anneal pulse. Figure 4 shows a $21 / 4$ inch diameter silicon wafer diamond scribed on its 
TABLE I

CONTACT STUDY SUMMARY

\begin{tabular}{|c|c|c|c|}
\hline $\begin{array}{l}\text { Contact } \\
\text { Material }\end{array}$ & $\begin{array}{l}\text { Deposition } \\
\text { Temperature }\end{array}$ & $\begin{array}{l}\text { Sintering } \\
\text { Condition }\end{array}$ & Behavior \\
\hline $\begin{array}{c}\text { Aluminum } \\
5 \mu\end{array}$ & $\begin{array}{l}26^{\circ} \mathrm{C} \\
26^{\circ} \mathrm{C} \\
26^{\circ} \mathrm{C}\end{array}$ & $\begin{array}{c}\text { None } \\
400^{\circ} \mathrm{C} / 5 \mathrm{~min} . \\
\text { Pulsed }\end{array}$ & $\begin{array}{l}370 \mathrm{mV} \text { barrier } \\
\text { ohmic } \\
\text { ohmic }\end{array}$ \\
\hline & $\begin{array}{l}250^{\circ} \mathrm{C} \\
250^{\circ} \mathrm{C} \\
250^{\circ} \mathrm{C}\end{array}$ & $\begin{array}{c}\text { None } \\
400^{\circ} \mathrm{C} / 5 \mathrm{~min} . \\
\text { Pulsed }\end{array}$ & $\begin{array}{l}\text { ohmic } \\
\text { ohmic } \\
\text { ohmic }\end{array}$ \\
\hline $\begin{array}{l}\text { Titanium- } \\
\text { Silver } \\
(0.1 \mu-3 \mu)\end{array}$ & $\begin{array}{l}26^{\circ} \mathrm{C} \\
26^{\circ} \mathrm{C} \\
26^{\circ} \mathrm{C}\end{array}$ & $\begin{array}{l}\text { None } \\
605^{\circ} \mathrm{C} / 5 \mathrm{~min} . \\
\text { Pulsed }\end{array}$ & $\begin{array}{r}450 \mathrm{mV} \text { barrier } \\
60 \mathrm{mV} \text { barrier } \\
270 \mathrm{mV} \text { barrier }\end{array}$ \\
\hline & $\begin{array}{l}250^{\circ} \mathrm{C} \\
250^{\circ} \mathrm{C} \\
250^{\circ} \mathrm{C}\end{array}$ & $\begin{array}{l}\text { None } \\
605^{\circ} \mathrm{C} / 5 \mathrm{~min} . \\
\text { Pulsed }\end{array}$ & $\begin{array}{r}240 \mathrm{mV} \text { barrier } \\
70 \mathrm{mV} \text { barrier } \\
280 \mathrm{mV} \text { barrier }\end{array}$ \\
\hline
\end{tabular}




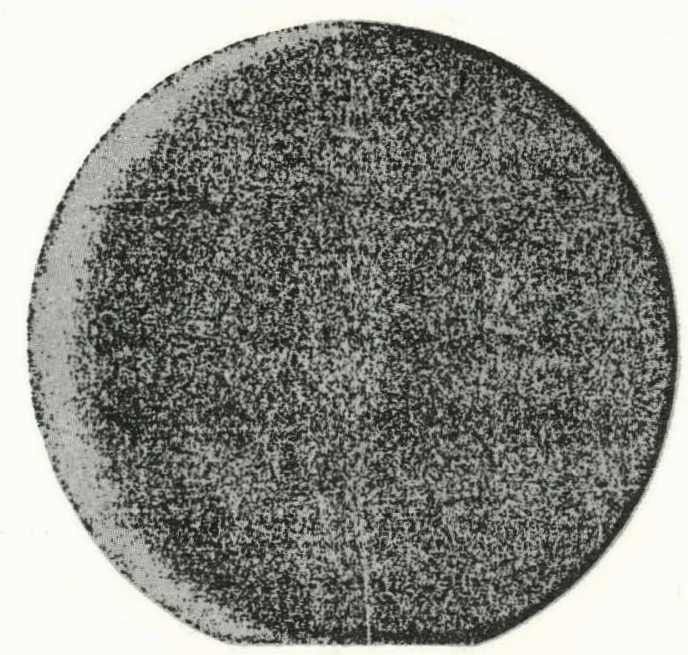

A. Scribed Wafer Before Pulse.

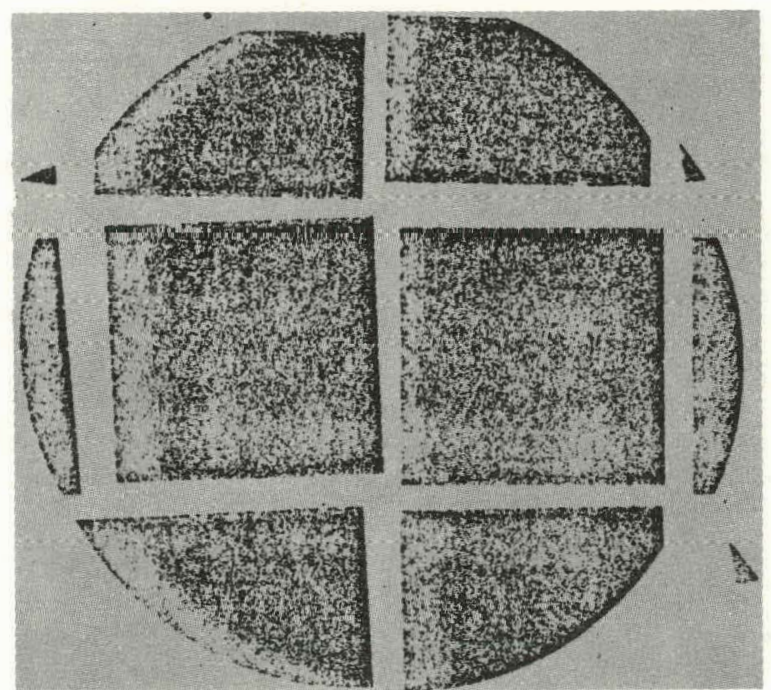

B. Wafer After Electron Pulse.

Figure 4. Wafer Sizing Using Transient Stress Wave Induced Fracture. 
back surface prior to junction implant and precisely fractured along the scribe pattern by the electron pulse used for the implant anneal.

2.4 Pulsed Electron Beam Development The electron beams being used for pulsed processing continue to involve a degradation mechanism which causes pulse processed cells to remain 5 to $10 \%$ lower in output than similar conventionally processed cells. Finished conventionally processed diffused or implanted junction cells also degrade 5 to $10 \%$ (lose 20 to $50 \mathrm{mV}$ of Voc) when subjected to the electron pulse. The effect is attributed to ion contamination of the electron beam which is difficult to eliminate because of the method by which the very high current electron pulse is generated. Necessary correction of the beam contamination problem is being performed under Air Force Aero Propulsion Laboratory Contract F33615-75-C-2006.

As part of the effort to eliminate possible sources of contaminants, the electron beam generation configuration is being modified. An immediate advantageous result has been that the uniform area available in the pulse has been increased from a spot large enough to process a $2 \times 2 \mathrm{~cm}$ cell to one sufficient to process a 3 inch diameter cell in a single pulse. 


\subsection{Processing Sequence}

In preparation for minimization of processing sequence duration, silicon wafer to finished cell, fabrications are now being timed. Because operations are performed in a number of separate pieces of apparatus rather than in a combined automated facility, handling, transfer and pump-down periods are not clocked. Present times for each operation of existing sequences for fabrication of $2 \times 2 \mathrm{~cm}^{+} \mathrm{NP}^{+}$cells using furnace and pulsed electron beam methods are summarized in Table II. Total times for the conventional and pulsed processes are 5423 and 371 seconds respectively. Most of the pulse process total resulted because the ion implanter was set up to scan a $7.6 \mathrm{~cm} \times 7.6 \mathrm{~cm}$ area even though the cell being prepared was only $2 \times 2 \mathrm{~cm}$. It is now apparent that the program goal of 120 seconds for a $2 \times 2 \mathrm{~cm}$ cell will be achieved and bettered. If 3 inch diameter cells are produced, processing time will drop from approximately 30 seconds per $\mathrm{cm}^{2}$ to less than 10 seconds per $\mathrm{cm}^{2}$ of cell surface area. 
PRESENT CELL PROCESS TIMES

\begin{tabular}{|c|c|c|}
\hline A. Conventional Processing & $\begin{array}{l}\text { Measured } \\
\text { Time }\end{array}$ & $\begin{array}{c}\text { Area } \\
\text { Dependent ? }\end{array}$ \\
\hline $\begin{array}{l}\text { 1. Implant } 10^{15} \mathrm{~cm}^{-2} \mathrm{p}^{31+} \\
\text { 2. Anneal } 750^{\circ} \mathrm{C} \\
\text { 3. Evaporate } 0.1 \mu \mathrm{m} \mathrm{Al} \text { on back } \\
\text { 4. Alloy at } 650^{\circ} \mathrm{C} \\
\text { 5. HF dip and } \mathrm{clean} \\
\text { 6. Evaporate } 1 \mu \mathrm{m} \mathrm{Al} \mathrm{back} \mathrm{contact} \\
\text { 7. Evaporate } 5 \mu \mathrm{m} \mathrm{Al} \mathrm{front} \mathrm{contact} \\
\text { 8. Evaporate } \mathrm{SiO}_{\mathrm{X}} \mathrm{AR} \text { coating } \\
\text { 9. Sinter } 300^{\circ} \mathrm{C}\end{array}$ & $\begin{array}{r}46 \text { sec } \\
2400 \\
25 \\
1500 \\
1064 \\
27 \\
37 \\
23 \\
300 \\
5423\end{array}$ & $\begin{array}{l}\text { Yes } \\
\text { No } \\
\text { Yes } \\
\text { No } \\
\text { No } \\
\text { Yes } \\
\text { Yes } \\
\text { Yes } \\
\text { No }\end{array}$ \\
\hline B. Pulsed Electron Beam Processing & & . \\
\hline $\begin{array}{l}\text { 1. Implant } 10^{15} \mathrm{~cm}^{-2} \mathrm{P}^{31+} \\
\text { 2. Implant } 10^{15} \mathrm{~cm}^{-2} \mathrm{~B}^{11+} \\
\text { 3. Anneal front with electron pulse } \\
\text { 4. Anneal back with electron pulse } \\
\text { 5. Evaporate } 1 \mu \mathrm{m} \mathrm{Al} \text { back contact } \\
\text { 6. Evaporate } 5 \mu \mathrm{m} A \text { front contact } \\
\text { 7. Evaporate SiO } \mathrm{AR} \text { coating } \\
\text { 8. Sinter front with electron pulse } \\
\text { 9. Sinter back with electron pulse }\end{array}$ & $\begin{array}{r}46 \\
233 \\
<1 \\
<1 \\
27 \\
37 \\
23 \\
<1 \\
<1 \\
371\end{array}$ & $\begin{array}{l}\text { Yes } \\
\text { Yes } \\
\text { No } \\
\text { No } \\
\text { Yes } \\
\text { Yes } \\
\text { Yes } \\
\text { No }\end{array}$ \\
\hline
\end{tabular}


3.0 CONCLUSIONS AND RECOMMENDATIONS

Development of optimized individual steps of the high rate, low energy expenditure fabrication procedure is, progressing satisfactorily. Program goals for processing time and energy consumption are being approached and should be achieved. Cell performance objective of $11 \%$ AMO has not been achieved and requires correction of an electron beam próblem which is specifically not addressed under this program. Present cell performance capability is 98 AMO. 
4. 0 APPENDICES

4.1 New Technology

No new technology has been identified during the period of this report.

4.2 Program Plan

An updated program schedule is given in Table III.

4.3 Man Hours and Costs

Total man-hours and costs for period of this report

(1) January - 31 March 1976) were 1,724 hours and $\$ 39,712$

respectively; from program inceptión, 3,289 hours and $\$ 75,009$ 


\begin{tabular}{|c|c|c|c|c|c|c|c|c|c|c|c|c|c|}
\hline \multirow{2}{*}{\multicolumn{2}{|c|}{ TASK }} & \multicolumn{12}{|c|}{ CONTRACT MONTH } \\
\hline & & 1 & 2 & 3 & 4 & 5 & 6 & 7 & 8 & 9 & 10 & $1 i$ & 12 \\
\hline & $\begin{array}{l}\text { Demonstrate } 11 \% \text { AMO Cell } \\
\text { without Thermal Processing }\end{array}$ & & & & & & & & & & & & \\
\hline 11 & $\begin{array}{l}\text { Identify Optimum Pulse Pro- } \\
\text { cess Parameters for Implant } \\
\text { Anneal and Sinter Operations }\end{array}$ & $\Delta$ & & & & & & & & & & & \\
\hline 111. & $\begin{array}{l}\text { Identify Optimum Room Temp- } \\
\text { erature Implantation Con- } \\
\text { ditions }\end{array}$ & & & & & & & & & & & & \\
\hline & $\begin{array}{l}\text { Identify Minimum Processing } \\
\text { Requirements for } 11-12 \% \text { AMO } \\
\text { Performance Cell }\end{array}$ & & & & & & 4 & & & & & & \\
\hline v. & $\begin{array}{l}\text { Reduce Direct Proçess Energy } \\
\text { to Below } 5 \mathrm{cal} / \mathrm{cm}^{2} \text { and Pro- } \\
\text { cessing Time to Below } 30 \\
\mathrm{sec} / \mathrm{cm}^{2}\end{array}$ & & & $\Delta$ & & & & & & & & & \\
\hline VI. & $\begin{array}{l}\text { Evaluate Cell Fabrication } \\
\text { Under Research Goal Objective } \\
\text { Constraints and deliver } 100 \\
\text { Cells to JPL. }\end{array}$ & & & & & & & & & & & & \\
\hline VII. & $\begin{array}{l}\text { Compare Performance and } \\
\text { Environmental Stability of }\end{array}$ & & & & & & & & & & & & \\
\hline & $\begin{array}{l}\text { Pulse Process and Conven- } \\
\text { tional Process Cells }\end{array}$ & & & & & & & & & & & & \\
\hline
\end{tabular}

Table 1. Program Schedule. 